\title{
Anti-Müllerian hormone (AMH) secretion in prepubertal and adult rams
}

\author{
O. Cazorla ${ }^{1,3}$, M. Seck ${ }^{2}$, C. Pisselet ${ }^{3}$, C. Perreau ${ }^{3}$, J. Saumande $^{3 *}$, \\ J. Fontaine ${ }^{3}$ M. de Reviers ${ }^{4}$ and M. T. Hochereau-de Reviers ${ }^{3}$ \\ ${ }^{1}$ Université de Tours, Laboratoire de Physiologie Animale, Parc de Grammont, 37000 Tours, \\ France; ${ }^{2}$ Laboratoire de Physiologie Animale, Université de Dakar, Sénégal; ${ }^{3}$ INRA PRMD-URA 1291 \\ Centre de Recherches de Tours, 37380 Nouzilly, France; and ${ }^{4}$ INRA SRA Centre de Recherches \\ de Tours, 37380 Nouzilly, France
}

\begin{abstract}
The aim of the present analysis was to determine whether anti-Müllerian hormone concentrations in prepubertal plasma or adult rete testis fluid are related to the number or function of Sertoli cells in rams or to the presence of the Fec ${ }^{\mathrm{B}}$ Booroola gene. Twenty rams from two Booroola crosses, differing in their testicular masses were analysed; in each cross, half of the animals were heterozygous carriers of the $\mathrm{Fec}^{\mathrm{B}}$ gene. The data from rams, during prepuberty and at adulthood during the non-sexual season, were analysed by two-way ANOVA and residual correlations. In 4-week-old intact male lambs, the mean anti-Müllerian hormone plasma concentration was $15 \mathrm{ng} \mathrm{ml}^{-1}$, irrespective of cross, genotype or eCG stimulation; it was significantly negatively correlated with FSH ( $r=-0.51 ; P=0.02 ; n=19)$. In adults, anti-Müllerian hormone was not detectable in plasma and was $0.5 \mathrm{ng} \mathrm{ml}^{-1}$ in rete testis fluid, irrespective of cross or genotype. The total number of Sertoli cells per testis was not related to anti-Müllerian hormone concentration in lamb prepubertal plasma or in adult rete testis fluid. The concentration of anti-Müllerian hormone in adult rete testis fluid was significantly and negatively correlated with the daily production of leptotene primary spermatocytes per testis $(r=-0.56 ; P=0.02 ; n=16)$. The mean oestrogen concentration in the adult testicular vein was $2 \mathrm{pg} \mathrm{ml}^{-1}$ and was correlated negatively with the rete testis fluid concentration of anti-Müllerian hormone $(r=-0.60 ; P=0.02 ; n=15)$ and correlated positively with the daily production of leptotene primary spermatocytes per testis $(r=0.53$; $P<0.05 ; n=19$ ). In conclusion, anti-Müllerian hormone secretion was not correlated with the total numbers of Sertoli cells per testis and cannot be used as a predictor of the number of Sertoli cells. Anti-Müllerian hormone secretions were not affected by the presence of $\mathrm{Fec}^{\mathrm{B}}$ gene. However, anti-Müllerian hormone secretion could be considered to be inversely related to the daily production of primary spermatocytes by the testis.
\end{abstract}

\section{Introduction}

The fetal male gonad secretes a protein that inhibits the formation of Müllerian ducts in males (Jost, 1947). AntiMüllerian hormone (AMH or Müllerian inhibiting substance or factor) is secreted by the fetal Sertoli cells surrounding the gonocytes (Tran et al., 1981, 1987) but the hormonal and local control of its secretion has yet to be clarified. The mRNA encoding $\mathrm{AMH}$ is regulated by dibutyryl cAMP but not by FSH or hCG in cultured human fetal testicular cells (Voutilainen and Miller, 1987). Similarly, secretion of the AMH by bovine Sertoli cells in primary culture is not modified by FSH or testosterone (Vigier et al, 1985). In contrast, in rat fetal or new-born testes in vivo, mRNA transcription of $\mathrm{AMH}$ is decreased by FSH treatment (Kuroda et al., 1990) and cleavage

*Correspondence.

Revised manuscript received 23 July 1997. or dissociation of $\mathrm{AMH}$ is increased by testosterone (Kuroda et al., 1991). Moreover, in boys presenting normal or precocious pubertal development, an inverse relationship between $\mathrm{AMH}$ and testosterone serum concentrations has been observed (Rey et al, 1993). However, in a longitudinal comparative analysis of $\mathrm{AMH}$, testis volume and hormonal plasma concentrations throughout puberty, no such relationship was observed (Hudson et al., 1990). Furthermore, Baker and Hutson (1993) hypothesized a positive control of $\mathrm{AMH}$ on the transformation from gonocytes to spermatogonia.

In females, the $\mathrm{Fec}$ B Booroola gene is known to affect litter size, ovulation rate, the pattern of follicular development and the onset of ovogenesis in the fetal ovary (McNatty et al., 1990, 1995). The role of the $\mathrm{Fec}^{\mathrm{B}}$ gene in the synthesis of oestrogen and on plasma concentrations of FSH in females is well documented. During the prepubertal period in males, the presence of a transient increase in $\mathrm{LH}$ and FSH plasma 
concentrations in heterozygous carriers of the $\mathrm{Fec}^{\mathrm{B}}$ gene was observed by Seck et al. (1988) but remains controversial. In adult rams, no obvious differences in hormonal secretions or in somatic or germ cell compositions of the testis were recorded in carriers of the $\mathrm{Fec}^{\mathrm{B}}$ gene (Hochereau-de Reviers and Seck, 1990). A role of an oestrogen-related mechanism, transiently expressed in males, could be suspected in the $\mathrm{Fec}^{\mathrm{B}}$ gene; because of the control of AMH synthesis by oestrogen (Guerrier et al., 1990), AMH secretion could be involved in $\mathrm{Fec}^{\mathrm{B}}$ gene expression.

In adult males, AMH has been detected at low concentrations in the rete testis fluid in boars (Josso et al., 1979) and bulls (Vigier et al., 1983). However, the relationships between its secretion by the Sertoli cells and the number of Sertoli cells (Rey et al., 1996) and spermatogenesis are unclear (Baarends et al., 1995). Therefore, in the present study, the relationships between $\mathrm{AMH}, \mathrm{LH}, \mathrm{FSH}$, oestrogen and testosterone secretions were explored before and after puberty in rams. Furthermore, the relationship between secretion of AMH and spermatogenesis was analysed in adult rams. This analysis was performed on males from two Booroola Merino crosses (Booroola $\times$ Mérinos d'Arles and Booroola $\times$ Romanov), which differed in the precocity of the onset of their testicular growth and in their mean adult testicular masses (Hochereau-de Reviers and Seck, 1990), to determine whether AMH secretion differed with the presence of $\mathrm{Fec}^{\mathrm{B}}$ gene. In each cross, half of the males were carriers and half were non-carriers of the $\mathrm{Fec}^{\mathrm{B}}$ gene but no difference in sperm production with the presence of the $\mathrm{Fec}^{\mathrm{B}}$ gene was observed (Hochereau-de Reviers and Seck, 1990).

\section{Materials and Methods}

\section{Materials}

Purified ovine LH (YC 1086 or 1051: $1 \mathrm{mg}$ of this preparation is equivalent to $2.1 \mathrm{mg}$ of LH-NIH-S1) was kindly provided by Y. Combarnous (URA 1291, PRMD, Nouzilly). FSH was donated by A. F. Parlow (FSH. NIH I 1 .NIADDK NIH, Bethesda ML; assays in prepubertal lambs) and $\mathrm{H}$. Grimek (FSH.HG.225; Madison, WI). 1,2,6,7 $\left.\left.\right|^{3} \mathrm{H}\right]$ testosterone $(88 \mathrm{Ci}$ $\mathrm{mmol}^{-1}$ ) and 2,4,6,7,16,17[ ${ }^{3} \mathrm{H}$ ]oestrogen ( $155 \mathrm{Ci} \mathrm{mmol}{ }^{-1}$ ) were purchased from the Radiochemical Centre (Amersham, Bucks). Non-labelled steroids were obtained from Steraloids (Wilton, NH). The testosterone antibody was obtained by immunization of rabbits against testosterone coupled with 3-carboxyl-methyl-amine saturated by BSA, kindly provided by G. Picaper (CHR, Orléans). The antibody against oestrogen was provided by J. Saumande and was obtained by immunization of rabbits against 6-ketoestradiol-17 $\beta$ 6- $(O-$ carboxymethyl) oxime conjugated to BSA. Equine CG (Chronogest) was purchased from Intervet (Boxmeer). $\mathrm{Na}{ }^{125} \mathrm{I}$ was purchased from Amersham International (Amersham, Bucks). The standard incubation medium of fetal calf testis was kindly provided by B. Vigier (Paris). Antibodies against bovine $\mathrm{AMH}$ (278 II and $61 \mathrm{~A}$; Vigier et al., 1985; Legeai et al., 1986) were generous gifts of F. Legeai and B. Vigier. ELISAs were performed in polystyrene plates (Microtest Luxlon ${ }^{\mathrm{B}}$; CEB, Angers) and read by a Titertek multiskan MKII. The horse serum used for dilution of plasma or RTF samples originated from Gibco (Paisley).

\section{Animals}

Experiment 1. Blood samples were collected from six normal and four castrated Ile de France lambs on 3 successive days when they were 6 weeks old (three blood samples per animal) to validate the enzyme immunoassay for plasma concentrations of $\mathrm{AMH}$ in prepubertal lambs.

Experiment 2. Blood samples were collected from fourteen prepubertal Booroola $\times$ Romanov male lambs $(4$ weeks old with an average weight of $8 \mathrm{~kg}$ ) at $14: 00 \mathrm{~h}$ and $16: 00 \mathrm{~h}$ on day 0 and at 9:00 h on day 1 to determine the daily variation in plasma concentrations of $\mathrm{AMH}$. In the same lambs, the influence of an increase in gonadotrophin and testosterone plasma concentrations on plasma concentrations of $\mathrm{AMH}$ was tested by injection of eCG ( $80 \mathrm{iu} \mathrm{kg}{ }^{-1}$ of body weight, i.m.) at 10:00 h on day 1 . The blood samples were collected at $6 \mathrm{~h}$ (day 1), $24 \mathrm{~h}$ and $30 \mathrm{~h}$ (day 2) after injection and the stimulation of testosterone secretion after these eCG injections was observed 24-48 $\mathrm{h}$ after injection (testosterone before injection: $0.5 \mathrm{ng}$ $\mathrm{ml}^{-1}$; $1-3$ days after injection: $3 \mathrm{ng} \mathrm{ml}^{-1}$; Hochereau-de Reviers et al., 1990).

Experiment 3. Blood samples were collected from prepubertal male lambs from crosses between Booroola $\mathrm{Fec}^{\mathrm{B}} \mathrm{Fec}^{+}$or $\mathrm{Fec}^{\mathrm{B}} \mathrm{Fec}^{\mathrm{B}}$ rams with ten Mérinos d'Arles ewes (BooMa in Domaine du Merle, ENSAM, 13300 Salon-de-Provence) or ten Romanov ewes (BooRo in Domaine de la Sapinière, INRA, 18390 Osmoy) once a week from 3 to 10 weeks of age. Each cross (BooMa and BooRo) contained five non-carriers $\mathrm{Fec}^{+}$ $\mathrm{Fec}^{+}$and five heterozygous carriers $\mathrm{Fec}^{\mathrm{B}} \mathrm{Fec}^{+}$, respectively. In BooRo lambs, the onset of testis growth was evaluated by comparative palpation and the lambs were weighed twice, at 4 and 6 weeks of age.

In the same BooRo and BooMa animals after puberty (at a similar mean body weight of $55-60 \mathrm{~kg}$ ), a cannula was inserted under halothane anaesthesia in the rete testis of one testis per ram (Dacheux et al., 1981) during the nonbreeding season, from the end of January to April. Rete testis fluid (RTF) was collected continuously in 16 of the 20 conscious animals; the hourly flow rate of RTF and the concentrations of spermatozoa in RTF were determined; concomitantly, blood samples were collected from animals at 9:00 h, 11:30 h, 14:30 h and 16:00 h. At castration, venous blood was sampled from the testicular vein just before the arrival of the vein in the pampiniform complex. The oestrogen secretion by the testis was estimated by analysis of its concentration in the testicular venous plasma.

\section{Testis analysis}

The testes of all BooRo and BooMa adult rams (Expt 3) were weighed and a piece $\left(1-3 \mathrm{~cm}^{3}\right)$ of parenchyma of one testis per ram was fixed in Bouin-Hollande solution. The histological analysis was performed as described by Hochereau-de Reviers et al. (1992). Briefly, the relative volume of intertubular tissue and of seminiferous tubules in the testicular parenchyma were 
determined with a 25-point integrator on 20 fields per testis at a magnification of $\times 160$; the relative volume of Leydig cells in the intertubular tissue was determined in the same way at a magnification of $\times 800$. The total volumes of seminiferous tubules and of intertubular tissue were then calculated by multiplying their relative volumes in the parenchyma by the total mass of the testis. The mean cross-sectional area was measured on 20 round sections of seminiferous tubules per testis with a camera lucida attached to a microscope and the use of the Tablet Graphic planimeter program (Apple Computers, Cupertino, CA). The total length of the seminiferous tubules was then calculated by division of their total volume by the mean seminiferous cross-sectional area (Attal and Courot, 1963). The cross-sectional areas of 20 Leydig cells and of 20 Sertoli cell nuclei measured at stage 8 (classification of RoosenRunge and Giesel, 1950) were determined using the same planimeter program at a magnification of $\times 800$. The mean numbers of Sertoli cell nuclei and of $A_{1}$ spermatogonia (stages $7-8$ ), of leptotene primary spermatocytes (end of stage 1 and stage 2) and round spermatids (stages 7-8) were counted on ten cross-sections of seminiferous tubules. The mean corrected number of cells per unit length was calculated after correction for nuclear size and section thickness $(10 \mu \mathrm{m})$ according to the method of Abercrombie (1946). The total numbers of Sertoli cells and germ cells per testis were then obtained by multiplying their number per unit length by the total length of seminiferous tubules per testis. The daily production of germ cells ( $A_{1}$ to round spermatids) was determined by division of their total number per testis by the mean duration of the seminiferous epithelium cycle in rams (Ortavant, 1959). The total volume of Leydig cells was obtained by multiplying their relative volume in the intertubular tissue by the total volume of intertubular tissue. Their total numbers were obtained by division of their total volume per testis by their mean individual volume, calculated from their mean cross-sectional area, and with the assumption that they were spherical. All values were corrected for shrinkage.

\section{Hormone assays}

Plasma concentrations of $\mathrm{LH}, \mathrm{FSH}$ and testosterone were determined by radioimmunoassays in prepubertal and adult BooMa and BooRo, in two separate assays according to age. LH was assayed by displacement (Pelletier et al., 1982); the detection level (B:Bo $=95 \%$ ) was $6 \mathrm{pg} \mathrm{ml}^{-1}$ of oLH 1051 or oLH 1086 and the intra-assay coefficient of variation was $10 \%$ for $\mathrm{B}: \mathrm{Bo}=50 \%$. FSH rabbit polyclonal antibody (AS5; Pelletier et al., 1982) was first incubated with oLH $\left(37^{\circ} \mathrm{C} ; 90 \mathrm{~min}\right)$ to eliminate crossreactivity with $\mathrm{LH}$ (Blanc and Poirier, 1979). The crossreactivity of FSH antibody with $\mathrm{LH}$ after this incubation is $0.02 \%$. The detection concentration of $\mathrm{FSH}(\mathrm{B}: \mathrm{Bo}=95 \%)$ was $2 \mathrm{ng} \mathrm{ml}^{-1}$ and the coefficient of variation for $\mathrm{B}: \mathrm{BO}=50 \%$ was $7 \%$. Plasma concentrations of testosterone were determined by a direct radioimmunoassay (Garnier et al,, 1978; modified by Hochereau-de Reviers et al., 1990). The detection level for $\mathrm{B}: \mathrm{Bo}=95 \%$ was $60 \mathrm{pg} \mathrm{ml}^{-1}$ and the coefficient of variation was $18 \%$ at $0.3 \mathrm{ng} \mathrm{ml}^{-1}$ and decreased to $<5 \%$ at 3 and $10 \mathrm{ng}$ $\mathrm{ml}^{-1}$. Oestrogens were measured after extraction in 1-2 ml of testicular venous plasma (Saumande, 1981). The detection limit of the assay was $0.5 \mathrm{pg} \mathrm{ml}^{-1}$ and the coefficient of variation was $12 \%$ at $20 \mathrm{pg} \mathrm{ml}^{-1}$ and decreased to $6 \%$ at $1 \mathrm{pg} \mathrm{ml}^{-1}$.

Plasma concentrations of $\mathrm{AMH}$ were determined with a two-site enzyme immunoassay adapted for ovine $\mathrm{AMH}$, using two different monoclonal $\operatorname{lgGI}$ antibodies, raised against purified bovine AMH described by Vigier et al. (1983) and Legeai et al. (1986). The monoclonal antibodies, $\mathrm{mAb} 61$ raised against purified bAMH $\left(K_{\mathrm{a}}=5.8 \times 10^{9}\right)$ and $\mathrm{mAb} 278$ raised against impure bAMH $\left(K_{\mathrm{a}}=17 \times 10^{9}\right)$, were used since their respective target epitopes were close to the biological activity site but different from each other. Furthermore, they crossreacted with AMH contained in fetal lamb sera (Legeai $e$ t al., 1982). The coating of polystyrene plates was obtained with $100 \mu \mathrm{lmAb} 278\left(6.15 \mu \mathrm{g} \mathrm{ml}^{-1}\right.$ in $\mathrm{Na}_{2} \mathrm{CO}_{3}, \mathrm{NaHCO}_{3} 0.2 \mathrm{~mol}$ $\mathrm{l}^{-1}, \mathrm{pH} 9.2$, for $1 \mathrm{~h}$ at $37^{\circ} \mathrm{C}$ and overnight at $4^{\circ} \mathrm{C}$ ). Saturation of residual binding sites was performed by an incubation in Tris buffer (Tris $0.1 \mathrm{~mol} \mathrm{l}^{-1}, \mathrm{NaCl} 0.15 \mathrm{~mol} \mathrm{l}^{-1}, \mathrm{pH} \mathrm{7.5)} \mathrm{containing}$ BSA $1 \mathrm{mg} \mathrm{ml}{ }^{-1}$ for $2 \mathrm{~h}$ at $37^{\circ} \mathrm{C}$. In addition, $100 \mu \mathrm{l}$ of plasma samples were incubated for $\mathrm{I} \mathrm{h}$ at $37^{\circ} \mathrm{C}$ and overnight at $4^{\circ} \mathrm{C}$; samples were either diluted (I/100 or $I / 50$ in PBS buffer containing 5\% heat-inactivated horse serum; equine AMH did not crossreact with these $\mathrm{mAb}$; Legeai et al., 1986), while RTF samples were not diluted because of their low protein content (1 $\mathrm{mg} \mathrm{ml}^{-1}$; Dacheux et al., 1981). After washing, the plates were exposed successively to the biotinylated (Josso et al., 1990) $\mathrm{mAb} 61\left(5 \mu \mathrm{g} \mathrm{ml}^{-1}\right.$ in Tris buffer containing $1 \mathrm{mg} \mathrm{BSA}$ $\mathrm{ml}^{-1}$ ) for $2 \mathrm{~h}$ at $37^{\circ} \mathrm{C}$, and then to the streptavidin-alkaline phosphatase complex diluted to $1 / 500$ in the same buffer. The colour reaction was obtained by addition of paranitrophenolphosphate $\left(1 \mathrm{mg} \mathrm{ml}^{-1}\right)$ in diethanolamine $10 \mathrm{mmol} \mathrm{l}^{-1}$, $\mathrm{MgCl}_{2} 1 \mathrm{mmol} \mathrm{1} 1^{-1}, \mathrm{pH} 9.5$ for $30 \mathrm{~min}$ at $37^{\circ} \mathrm{C}$ : the $15 \mathrm{~min}$ absorbance was half that of $30 \mathrm{~min}$ of incubation. The reaction was stopped by addition of $50 \mu \mathrm{l} 0.1 \mathrm{~mol}$ glycine $\mathrm{l}^{-1}$ to each well. Absorbance was read at $405 \mathrm{~nm}$. Increasing doses of an incubation medium of fetal calf testis containing high concentrations of bAMH were used as standard of calibration for each plate. The regression curves were drawn and did not differ significantly from each other: the mean of 14 slopes was 0.99236 with a SD of 0.0466 . All samples were assayed in duplicate. The minimal detection of the assay was $20 \mathrm{pg} \mathrm{ml}^{-1}$ and the intra-assay coefficient of variation at $\mathrm{B}: \mathrm{BO}=50 \%$ was $<5 \%$.

\section{Statistical analyses}

The effects of cross and of genotype intra-cross were analysed by a two-way analysis of variance (GLM procedure; type III SAS system). Residual Pearson correlation coefficients, corrected for the variation due to cross and to genotype intracross, were then calculated (SAS system). In addition, Spearman's rank correlation analysis was performed to analyse the relationships between $\mathrm{AMH}$ concentrations and total numbers of Sertoli cell per testis.

\section{Results}

The results presented (Tables $I$ and 2) relate to cross differences (BooRo and BooMa) as no genotype ( $\mathrm{Fec}^{\mathrm{B}}$ or ++ ) differences were observed, irrespective of age. However, the 
Table 1. Mean \pm SD plasma hormone concentrations $\left(\mathrm{ng} \mathrm{ml}^{-1}\right)$ of prepubertal and adult male sheep

\begin{tabular}{|c|c|c|c|}
\hline \multirow[b]{2}{*}{ Age } & \multirow[b]{2}{*}{ Hormone } & \multicolumn{2}{|c|}{ Crossbreed } \\
\hline & & BooRo & BooMa \\
\hline \multirow[t]{4}{*}{1 month } & Anti-Müllerian hormone in plasma & $14.69 \pm 4.13$ & $12.64 \pm 3.98$ \\
\hline & LH & $0.89 \pm 0.41^{\mathrm{a}}$ & $0.35 \pm 0.36^{\mathrm{b}}$ \\
\hline & FSH & $4.28 \pm 1.64$ & $5.60 \pm 1.33$ \\
\hline & Testosterone & $1.20 \pm 0.50^{\mathrm{a}}$ & $0.67 \pm 0.60^{b}$ \\
\hline \multirow[t]{3}{*}{$1.0-2.5$ months } & LH & $0.82 \pm 0.23$ & $0.80 \pm 0.72$ \\
\hline & FSH & $4.87 \pm 1.18$ & $5.15 \pm 1.07$ \\
\hline & Testosterone & $1.08 \pm 0.42^{\mathrm{a}}$ & $0.62 \pm 0.27^{b}$ \\
\hline \multirow[t]{3}{*}{ Adult } & LH & $1.41 \pm 1.33^{\mathrm{a}}$ & $0.40 \pm 0.38^{b}$ \\
\hline & FSH & $3.12 \pm 0.60$ & $3.30 \pm 1.08$ \\
\hline & Testosterone & $1.02 \pm 1.04$ & $0.58 \pm 0.82$ \\
\hline
\end{tabular}

${ }^{\mathrm{ab}}$ Significantly different means.

genotype was always taken into account for variance analysis and the correlations were always residual ones to exclude any false interpretation. Only correlations related to $\mathrm{AMH}$, oestrogen, gonadotrophins and testosterone, and spermatogenesis were presented.

Anti-Müllerian homone in peripheral plasma and testis growth of male prepubertal lambs

Experiment 1. AMH was not detected in castrated lamb plasma while in normal prepubertal $4-6$ week-old lambs, the mean plasma concentrations of $\mathrm{AMH}$ were $15 \mathrm{ng} \mathrm{ml}^{-1}$.

Experiment 2. AMH concentration in the three serial blood samples taken at the same age did not vary significantly in the same animal. The mean coefficient of variation in the same lamb was $17 \%$. There was no significant variation between morning $\left(17.8 \pm 4.5 \mathrm{ng} \mathrm{ml}^{-1}\right)$ and afternoon (17.2 $\pm 3.4 \mathrm{ng} \mathrm{ml}^{-1}$ ) samples; the correlation coefficient between the two values per animal was $0.83(n=7)$.

Exogenous eCG injection, which increased testosterone plasma concentrations threefold, did not significantly modify the $\mathrm{AMH}$ concentration at $6-30 \mathrm{~h}$ after injection (before eCG: $15.9 \pm 2.8 \mathrm{ng} \mathrm{ml}^{-1}, \mathrm{CV}=18 \%$; and after eCG: $17.1 \pm 3.7 \mathrm{ng}$ $\mathrm{ml}^{-1}, \mathrm{CV}=22 \%$ ).

Experiment 3. In young prepubertal lambs, the mean $\mathrm{AMH}$ concentration did not vary with breed or cross: Ile de France: $14.00 \pm 2.6 \mathrm{ng} \mathrm{ml}^{-1}$; BooRo: $14.7 \pm 4.1 \mathrm{ng} \mathrm{ml}^{-1}$ and BooMa: $12.7 \pm 4.0 \mathrm{ng} \mathrm{ml}^{-1}$. At 4 weeks of age, plasma concentrations of AMH did not differ significantly between cross and genotype; however, the mean coefficient of variation between animals, intracross and intragenotype, varied from 22 to $37 \%$. Furthermore, in BooRo lambs, the mean plasma concentrations of $\mathrm{AMH}$ decreased by $30 \%$ between 4 (17.6 $\pm 3.9 \mathrm{ng} \mathrm{ml}^{-1}$ ) and 5 (11.8 $\pm 2.7 \mathrm{ng} \mathrm{ml}^{-1}$ ) weeks of age, irrespective of the genotype and the onset of testis growth.

\section{Gonadotrophins and testosterone in prepubertal lambs}

FSH did not differ significantly between BooRo and BooMa lambs but $\mathrm{LH}(+154 \% ; P<0.01 \%)$ and testosterone $(+79 \%$;
$P=0.05)$ were significantly higher in BooRo than in BooMa lambs (Table 1). During the entire period between 4 and 10 weeks of age, BooRo male lambs had higher plasma concentrations of testosterone $(+74 \% ; P=0.01 ; n=20)$ than did BooMa lambs. At 5 weeks of age, the onset of testis growth had begun in 5/10 BooRo lambs, irrespective of genotype (mean testis volume $=4.2 \pm 1.1 \mathrm{ml}$ ), while it had not taken place in any BooMa lambs (testis volume $\leq 3 \mathrm{ml}$ ). At 4 weeks of age, AMH and FSH plasma concentrations were significantly negatively correlated $(r=-0.51 ; P=0.02 ; n=19)$. The testis volumes of BooRo lambs at 4 weeks of age were significantly related to the mean testosterone plasma values during the entire period between 4 and 10 weeks of age $(r=0.75$; $P<0.01 ; n=10)$ and to the body weight $(r=0.92 ; P<0.01$; $n=10)$ but not to the plasma concentrations of AMH. However, the variations in plasma concentrations of $\mathrm{AMH}$ of prepubertal lambs were not related to their testosterone plasma concentrations at either 4 weeks of age or during the whole period between 4 and 10 weeks of age $(n=19)$. When plasma concentrations of $\mathrm{AMH}$ were compared with total numbers of Sertoli cells per adult testis, no linear or rank correlations were observed.

Anti-Müllerian hormone in adult rete testis fluid and oestrogen in testicular venous plasma of adult rams

AMH was detected in RTF samples but no measurable AMH concentration was observed in the ovine testicular vein or testicular lymph. The mean AMH concentration, measured in three successive non-diluted samples of RTF of the same ram, was below $1 \mathrm{ng} \mathrm{mI}^{-1}$, and the coefficient of variation between samples from the same animal was $\leq 20 \%$. Mean AMH concentration did not differ with cross (BooRo: $0.52 \pm 0.37$; BooMa: $0.55 \pm 0.38 \mathrm{ng} \mathrm{ml}^{-1}$ ) or genotype; however, the mean coefficient of variation between rams, intracross and intragenotype, was very high (38-100\%). Oestrogen concentrations in the testicular vein were $5 \mathrm{pg}$ $\mathrm{ml}^{-1}$ and did not differ with the cross (BooRo: 5.29 \pm 5.06;

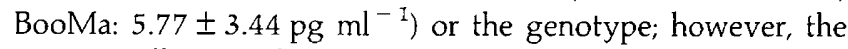
mean coefficient of variation between rams, intracross and intragenotype, was very high (40-85\%). 
Table 2. Mean \pm SD testicular parameters in adult rams from samples collected during the non-breeding season

\begin{tabular}{|c|c|c|}
\hline \multirow[b]{2}{*}{ Parameter } & \multicolumn{2}{|c|}{ Crossbreed } \\
\hline & BooRo & BooMa \\
\hline Testis weight $(\mathrm{g})$ & $165 \pm 31^{a}$ & $211 \pm 42^{\mathrm{b}}$ \\
\hline Leydig cell cross-sectional area $\left(\mu \mathrm{m}^{2}\right)$ & $64 \pm 5^{a}$ & $58 \pm 8^{\mathrm{b}}$ \\
\hline Number of Leydig cells per testis $\times 10^{8}$ & $40.3 \pm 12.0^{\mathrm{a}}$ & $73.3 \pm 26.0^{\mathrm{b}}$ \\
\hline Total length of seminiferous tubule per testis (m) & $2199 \pm 375^{\mathrm{a}}$ & $2750 \pm 639^{b}$ \\
\hline Seminiferous tubule diameter $(\mu \mathrm{m})$ & $226 \pm 12$ & $223 \pm 18$ \\
\hline Number of Sertoli cells per testis $\times 10^{8}$ & $23.6 \pm 4.1$ & $28.3 \pm 6.7$ \\
\hline Sertoli nuclear area $\left(\mu \mathrm{m}^{\frac{1}{2}}\right)$ & $57 \pm 5^{\mathrm{a}}$ & $72 \pm 4^{b}$ \\
\hline Number of $A_{0}$ spermatogonia per testis $\times 10^{7}$ & $2.37 \pm 0.67$ & $2.63 \pm 1.02$ \\
\hline Daily production of $A_{1}$ spermatogonia per testis $\times 10^{7}$ & $2.64 \pm 0.87$ & $3.08 \pm 0.84$ \\
\hline Daily production of leptotene primary spermatocytes $\times 10^{8}$ & $6.77 \pm 2.00$ & $8.10 \pm 3.42$ \\
\hline Daily production of round spermatids $\times 10^{9}$ & $2.03 \pm 0.41$ & $2.28 \pm 0.57$ \\
\hline Rete testis fluid flow rate $\left(\mathrm{ml} \mathrm{day}^{-1}\right)$ & $1.17 \pm 0.31^{\mathrm{a}}$ & $1.60 \pm 0.36^{\mathrm{b}}$ \\
\hline Number of spermatozoa in rete testis fluid $\times 10^{6} \mathrm{ml}^{-1}$ & $217 \pm 196$ & $182 \pm 106$ \\
\hline Rete testis fluid protein content $\left(\mathrm{mg} \mathrm{ml}^{-1}\right)$ & $1.34 \pm 0.82$ & $1.51 \pm 0.96$ \\
\hline
\end{tabular}

${ }^{a b}$ Significantly different means.

\section{Gonadotrophins and testosterone in adult rams}

In adulthood, during the non-breeding season, BooRo rams had significantly higher $(+250 \% ; P=0.04 ; n=18)$ plasma concentrations of LH than those of BooMa rams; however, their respective plasma concentrations of FSH and testosterone did not differ significantly (Table 1 ). The presence of the $\mathrm{Fec}^{\mathrm{B}}$ gene did not significantly modify the hormonal plasma concentrations.

\section{Testis parameters}

BooRo rams exhibited lower mean testis weights $(-22 \%$; $P=0.01 ; n=20)$, total number of Leydig cells $(-45 \%$; $P=0.002 ; n=10)$, total length or total volume of seminiferous tubules $(-20 \% ; P=0.03 ; n=20)$, total number of Sertoli cells $(-17 \% ; P=0.07 ; n=20)$ and daily RTF flow rate per testis $(-37 \% ; P=0.025 ; n=16)$ than BooMa rams (Table 2$)$, irrespective of genotype.

The daily production of germ cells and the concentrations of proteins and of spermatozoa in RTF did not differ significantly between the two crosses (Table 2). The mean cross-sectional areas of Sertoli cell nuclei were lower in BooRo than in BooMa rams $(-20 \% ; \quad P<0.001 ; n=20)$, while the mean crosssectional areas of Leydig cell were higher in Booko than in BooMa rams $(+11 \% ; P=0.05 ; n=20)$.

\section{Relationship between AMH secretions, prepubertal or adult hormonal and testicular parameters}

The AMH concentration in RTF of adult rams were significantly negatively correlated with the oestrogen concentration in the testicular vein $(r=-0.60 ; P=0.02 ; n=15)$. However, AMH concentration in the RTF of adult rams was not correlated with prepubertal plasma AMH concentrations $(n=16)$ or with adult FSH $(n=15), \mathrm{LH}(n=15)$ or testosterone

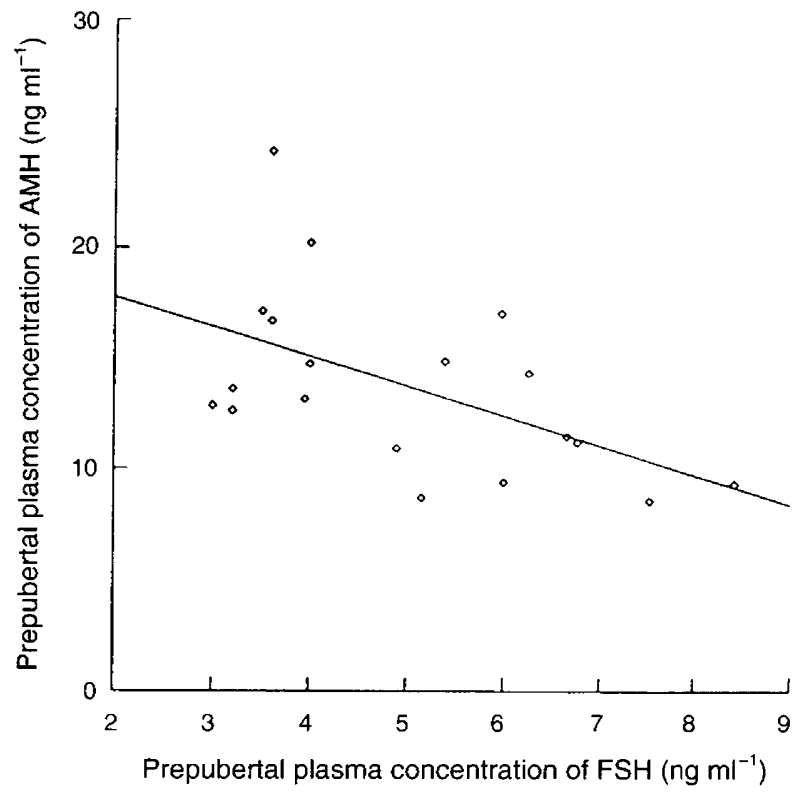

Fig. 1. Relationship between the concentrations of anti-Müllerian hormone $(\mathrm{AMH})$ and FSH in jugular venous plasma at 4 weeks of age in 19 crossbred Booroola lambs $(r=-0.51 ; P<0.05)$.

( $n=14)$ concentrations in plasma during the same period. However, the oestrogen concentration in the testicular vein was positively correlated with the mean FSH plasma concentrations ( $r=0.66 ; P=0.004 ; n=17 ;$ Fig. 1$)$ and with the mean testosterone plasma concentrations $(r=0.58 ; P=0.02 ; n=16)$.

The AMH concentrations in RTF or the oestrogen concentrations in the testicular vein were not related to any Sertoli or Leydig cell parameters. However, the daily productions of leptotene primary spermatocytes were significantly positively correlated with the oestrogen testicular venous plasma concentration ( $r=0.53 ; P=0.02 ; n=18$; Fig. $2 \mathrm{a})$ and negatively 
(a)

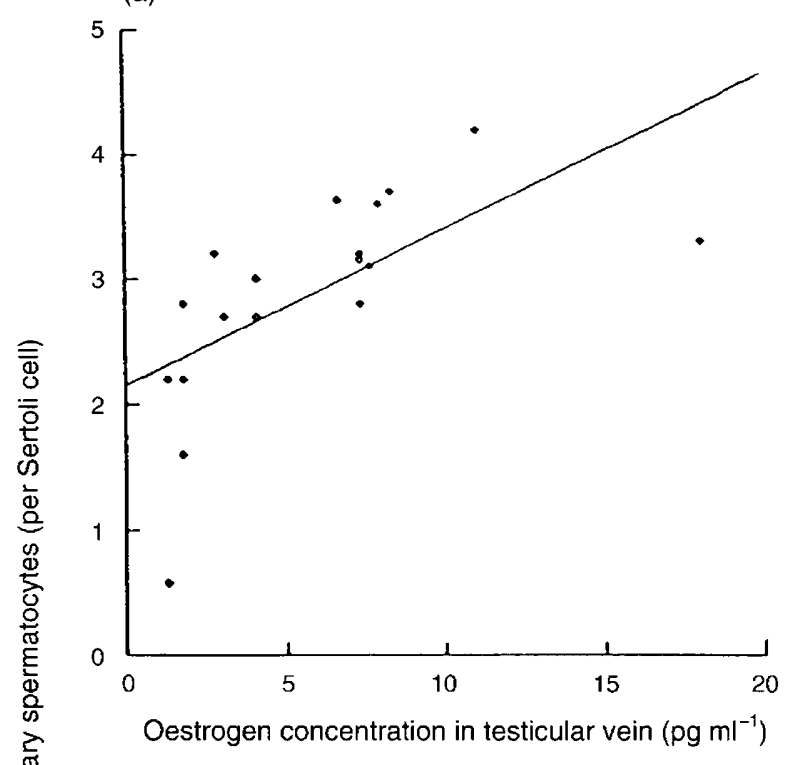

(b)

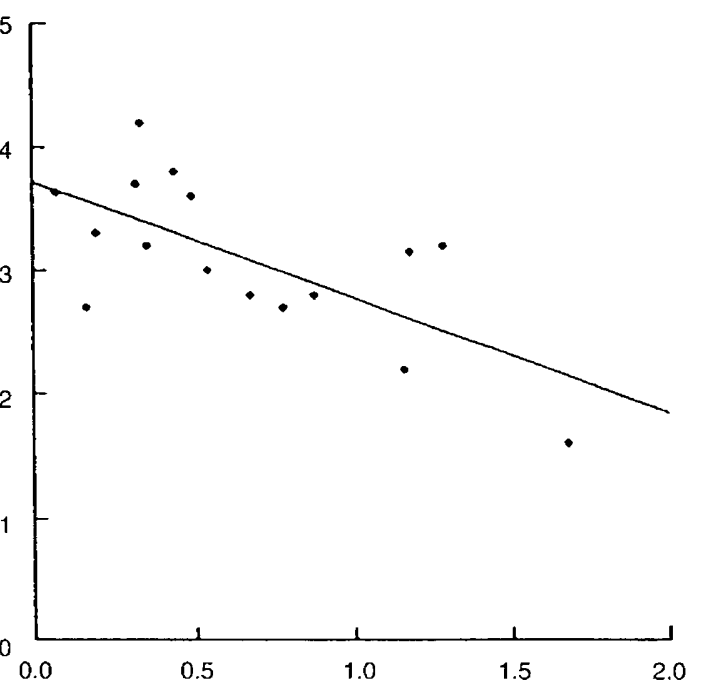

AMH in RTF (ng ml ${ }^{-1}$ expressed per $10^{7}$ Sertoli cells)

Fig. 2. Relationships between the daily production of leptotene primary spermatocytes expressed per Sertoli cell and: (a) oestrogen concentration ( $\left.\mathrm{pg} \mathrm{ml}^{-1}\right) \mathrm{g}^{-1}$ of testis $(r=+0.53 ; P=0.05 ; n=19)$; (b) anti-Müllerian hormone (AMH) concentration $\left(\mathrm{ng} \mathrm{ml}^{-1}\right.$ expressed per $10^{7}$ Sertoli cells) in the rete testis fluid (RTF) $(r=-0.56 ; P<0.05$; $n=16$ ).

correlated with the AMH concentration in the RTF $(r=-0.56$; $P=0.02 ; n=16$; Fig. 2b).

\section{Discussion}

The immunoassay used in the present study did not crossreact with other non-gonadal proteins, as no activity was observed after castration. The AMH concentrations observed in prepubertal lambs corresponded to those obtained by Legeai et al.
(1986) in near-term male fetal ovine sera. The AMH is secreted by the testes with no evidence of sharp fluctuations among successive samples or with time of day, confirming previous data concerning the low amount of fluctuation (Lee et al., 1994). Furthermore, injection of eCG, which possessed LH and FSH activities and stimulated testosterone production in the same lambs (before injection: $0.5 \mathrm{ng} \mathrm{ml}^{-1}$; and 1-3 days after injection: $3 \mathrm{ng} \mathrm{ml}^{-1}$; Hochereau-de Reviers et al., 1990), did not modify the $\mathrm{AMH}$ plasma concentration within the period of sampling $(6-30 \mathrm{~h}$ later). These results corroborate previous data obtained in vitro with Sertoli cell cultures, which show the absence of modulation of AMH secretion by FSH, LH or testosterone (Vigier et al., 1985; Voutilainen and Miller, 1987). However, in 4-week-old lambs, a negative correlation between plasma FSH and AMH concentrations was observed; this negative relationship could be an indirect effect of differentiation of the Sertoli cells that modify the AMH degradation. In rat fetuses it has been suggested that FSH downregulates $\mathrm{AMH}$ transcription and that $\mathrm{LH}$ and sex steroids play a role in the control of AMH processing (Kuroda et al, 1991). During the prepubertal period, BooRo lambs had higher plasma concentrations of testosterone than did BooMa lambs (Hochereau-de Reviers and Seck, 1990), but no relationship between $\mathrm{AMH}$ and testosterone plasma concentrations was observed in the present study. This could be due to the variability of plasma concentrations of testosterone as a consequence of the pulsatility of testosterone secretion; however, in weekly samples, which allow a mean estimation of the whole testosterone production, no correlation between AMH and testosterone was observed. The negative relationships observed in human males between testosterone, testicular growth and plasma concentrations of AMH remain controversial (Kuroda et al., 1991; Baker and Hutson, 1993; Lee et al., 1994). Most observations are based on comparisons between precocious or delayed and normal puberty at a given age. In a longitudinal analysis in vivo in the pubertal Cynomolgus monkey, it was observed that plasma concentrations of AMH were highly negatively correlated with testis volume, body weight and age, but not with testosterone plasma concentrations (Lee et al., 1994). In boars, AMH secretion in the blood is maintained until pubertal testicular growth is achieved (Tran et al., 1981). In the present study, BooRo lambs showed a $30 \%$ decrease in $\mathrm{AMH}$ concentration at the beginning of testis growth but without correlation between AMH plasma concentration and testis volume.

No correlation was observed between the prepubertal plasma AMH concentrations and the number of Sertoli cells in the same animals as adults; moreover, the BooRo lambs, which had the smallest number of Sertoli cells as adults, exhibited the same plasma concentrations of $\mathrm{AMH}$ as the BooMa, which had $20 \%$ more Sertoli cells (Hochereau-de Reviers and Seck, 1990; $P=0.07$ ). In sheep, the Sertoli cells cease division around I month of age (Monet-Kuntz et al., 1984) and the numbers of Sertoli cells per testis do not vary significantly later on (Hochereau-de Reviers and Courot, 1995). The concentration of AMH at 1 month of age in the present study could not be used as a predictor of the total numbers of Sertoli cells per adult testis.

In adult rams, $\mathrm{AMH}$ is present at a low but detectable concentration in the RTF $\left(0.5 \mathrm{ng} \mathrm{ml}^{-1}\right)$ as has been observed in 
pig RTF and bovine seminal plasma (Josso et al,, 1979; Vigier et al., 1985). AMH was not detected in the lymph or in the venous testicular plasma and, if it is present in ovine plasma, its concentration is lower than the minimal detection limit (0.02 $\mathrm{ng} \mathrm{ml}^{-1}$ ). Hudson et al. (1990) observed an AMH concentration of $0.5 \mathrm{ng} \mathrm{ml}{ }^{-1}$ in human adult serum which equalled the concentration observed in the present study in the RTF. The concentration of AMH in ovine RTF was much lower (20-25-fold) than that observed in peripheral plasma of the same animals before puberty. This difference is larger than that observed in humans (Hudson et al., 1990; Rey et al., 1993; Lee et al., 1994).

The secretion of AMH by adult Sertoli cells towards the adluminal compartment and into the RTF did not differ significantly between the two crosses, although the mean testis mass differed between crosses. However, in terms of Sertoli cell function, the production of germ cells expressed per Sertoli cell did not differ between the crosses (Hochereau-de Reviers and Seck, 1990). The negative correlation observed between daily production of leptotene primary spermatocytes, expressed per testis or per Sertoli cell, and the AMH concentration in RTF, has not been observed previously. This finding could be compared with the absence of spermatogonial differentiation from gonocyte multiplications in the presence of high concentrations of AMH in the fetus (Jost, 1947). Moreover, at the onset of spermatogenesis, in both normal and intersex patients, $\mathrm{AMH}$ was present in premeiotic seminiferous tubules but was no longer detected in neighbouring tubules with meiotic development (Rey et al., 1996). In the ovine testis, this could represent a seasonal imbalance of differentiated and undifferentiated secretions by the Sertoli cells, which varies among individuals, as has been observed in adult men (Rajpert-De Meyts and Skakkebaek, 1996). Moreover, in rats, the mRNA encoding $\mathrm{AMH}$ receptor II varies with stage of the seminiferous epithelium cycle and is maximal at stage VII when B type spermatogonia divisions occur (Baarends et al., 1995), just before the formation of leptotene primary spermatocytes.

The concentrations of oestrogen observed in testicular venous plasma in the present study were comparable with those of Ile de France rams during the sexual season (Setchell et al., 1991). Moreover, in hypophysectomized-hypophyseal extract-treated rams, the testicular venous concentration of oestrogen increased with plasma concentrations of FSH (Setchell et al., 1991). The correlations observed between oestrogen concentrations in the testicular venous plasma, the AMH concentration in the RTF and the production of leptotene primary spermatocytes could depend on the same local control of the Sertoli cell function by the germ cells or on the direct control of oestrogen on AMH synthesis. The promoter of the $\mathrm{AMH}$ gene contains an oestrogen response element (Guerrier et al., 1990). In mice in which the oestrogen receptor has been knocked-out, the daily production of spermatozoa per testis was decreased by half, and the epithelium in many of the seminiferous tubules appeared to have been sloughed (Hess et al. 1996). Moreover, in rats, aromatase was detected in germ cells (Nitta et al., 1993). However, when spermatogenesis was disrupted by heating the testes (Hochereau-de Reviers et al., 1993), in the absence of feedback control by the hypophysis, there was no modification of oestrogen plasma concentration in the venous testicular plasma (Setchell et al., 1991). The oestrogen concentration in the testicular vein appeared to be independent of the number of germ cells present.

In contrast to a previous study demonstrating that the $\mathrm{Fec}^{\mathrm{B}}$ gene carriers, on average, exhibited higher plasma concentrations of $\mathrm{FSH}$ and $\mathrm{LH}$ and lower testosterone than noncarriers from 4 to 8 weeks of age, irrespective of the cross (Seck et al., 1988), in this smaller sample of lambs, significant differences among genotypes in gonadotrophin or testosterone plasma concentrations were not observed. Consequently, the negative correlation observed at 4 weeks of age between FSH and $\mathrm{AMH}$ was not related to the presence of the $\mathrm{Fec}^{\mathrm{B}}$ gene in half of the lambs of each cross. In blood samples from adult rams during sexual or non-sexual seasons, gonadotrophin, testosterone or oestrogen concentrations did not differ with genotype (Hochereau-de Reviers and Seck, 1990). Similarly, the secretion of AMH by adult Sertoli cells into the RTF did not differ significantly between carriers and non-carriers of the $\mathrm{Fec}^{\mathrm{B}}$ gene. In terms of Sertoli cell function, the production of germ cells expressed per Sertoli cell did not differ according to the presence of the $\mathrm{FeC}^{\mathrm{B}}$ gene (Hochereau-de Reviers and Seck, 1990). The presence of the $\mathrm{Fec}^{\mathrm{B}}$ gene did not modify the secretion of $\mathrm{AMH}$, or its relationship with oestrogen or germ cell production by the testis, and it seems unlikely that $\mathrm{AMH}$ is involved in $\mathrm{Fec}^{\mathrm{B}}$ gene expression.

In conclusion, the AMH secretion by Sertoli cells could not be used as a predictor of the numbers of Sertoli cells. AMH secretions in prepubertal or adult rams did not vary with the presence of the $\mathrm{Fec}^{\mathrm{B}}$ gene but may be considered to be inversely related to the daily production of primary spermatocytes.

The authors gratefully acknowledge N. Josso, L. Legeai and B. Vigier for their help with ELISA and providing antibodies and bovine standard for AMH. This work on $\mathrm{Fec}^{\mathrm{B}}$ gene carriers and non-carriers rams was funded by an EEC grant Agromed (number 920232). The authors gratefully acknowledge all the members of the 'Boomarov' group for the management of the animals, particularly the staffs of Domaine de la Sapinière and of Domaine du Merle, the Hormonal Assay Unit for testosterone and LH assays in the adult rams and P. Lonergan for his help with the English.

\section{References}

Abercrombie M (1946) Estimation of nuclear population from microtome sections Anatomical Record 94 238-248

Attal J and Courot M (1963) Développement testiculaire et établissement de la spermatogenèse chez le taureau Annales de Biologie animale, Biochimie, Biophysique $3219-241$

Baarends WM, Hoogerbrugge JW, Post M, Visser JA, de Rooij DG, Parvinen M, Themmen APN and Grootegoed JA (1995) Anti-Müllerian hormone (AMH) and AMH type II receptor (AMHRII) messenger ribonucleic acid expression during postnatal testis development and the adult testis of the rat Endocrinology $1365614-5622$

Baker ML and Hutson JM (1993) Serum levels of Mullerian inhibiting substance in boys throughout puberty and in the first two years of life Journal of Clinical Endocrinology and Metabolism 76 245-247

Blanc MR and Poirier JC (1979) A new homologous radioimmunoassay for ovine follicle stimulating hormone: development and characterisation Annales de Biologie animale, Biochimie, Biophysique, 19 I01 I-1026

Dacheux JL, Pisselet C, Blanc MR, Hochereau-de Reviers MT and Courot M (1981) Seasonal variations in rete testis fluid secretion and sperm production in different breeds of ram Journal of Reproduction and Fertility 61 363-371 
Garnier DH, Cotta $Y$ and Terqui $M$ (1978) Androgen radioimmunoassay in the ram: results of direct plasma testosterone and dehydroepiandrosterone measurement and physiological evaluation Annales de Biologie animale, Biochimie, Biophysique 18 265-281

Guerrier D, Boussin L, Mader S, Josso N, Kahn A and Picard JY (1990) Expression of the gene for anti-Müllerian hormone Journal of Reproduction and Fertility $\mathbf{8 8}$ $695-706$

Hess RA, Bunick D, Seo K and lubahn DB (1996) Adult estrogen receptor knock-out mice have abnormal seminiferous tubules, rete testes and efferentes ductules Journal of Andrology Supplement P-38 Abstract 63

Hochereau-de Reviers MT and Courot M (1995) Rôle de l'évolution du testicule foetal sur la production de spermatozoïdes par le testicule adulte $2^{\text {ieme }}$ Rencontre Recherche Ruminants pp 417-420 Ed. Institut de l'Elevage, Paris

Hochereau-de Reviers MT and Seck M (1990) The male reproductive biology in prolific ovine breeds. In Major Genes for Reproduction in Sheep Eds JM Elsen and L Bodin. Colloques INRA 57 177-196

Hochereau-de Reviers MT, Copin M, Seck M, Monet-Kuntz C, Cornu C, Fontaine I. Perreau C, Elsen JM and Boomarov O (1990) Stimulation of testosterone production in the ovine male: effect of breed and age and application to males carrying or not the 'F' Booroola gene Animal Reproduction Science 23 21-32

Hochereau-de Reviers MT, Perreau C, Pisselet C and Pelletier J (1992) Effect of a 2-month light cycle regimen on testicular parameters of adult lle de France rams Microscopy Research and Technique $20268-273$

Hochereau-de Reviers MT, Locatelli A, Perreau C, Pisselet C and Setchell BP (1993) Effects of a single brief period of moderate heating of the testes on seminiferous tubules in hypophysectomized rams treated with pituitary extract Journal of Reproduction and Fertility 97 381-387

Hudson PL, Douglas I, Donahoe PK, Cate RL, Epstein J, Pepinsky RB and MacLaughlin DT (1990) An immunoassay to detect human Müllerian inhibiting substance in males and females during normal development journal of Clinical Endocrinology and Metabolism 70 16-27

Josso N, Picard JY, Dacheux JL and Courot M (1979) Detection of anti-Müllerian activity in boar rete testis fluid Journal of Reproduction and Fertility $\mathbf{5 7}$ $397-400$

Josso N, Legeai L, Forest MG, Chaussain JL and Brauner R (1990) An enzyme linked immunoassay for anti-Müllerian hormone: a new tool for the evaluation of testicular function in infants and children Joumal of Clinical Endocrinology and Metabolism 70 23-27

Jost A (1947) Recherches sur la différenciation sexuelle de l'embryon de lapin. III. Rôle des gonades foetales dans la différenciation sexuelle somatique Archives d'Anatomie microscopique et de Morphologie expérimentale 36 271-315

Kuroda T, Lee MM, Haqq CM, Powell OM, Manganaro TF and Donahoe PK (1990) Müllerian inhibiting substance ontogeny and its modulation by follicle-stimulating hormone Endocrinology 127 1825-1832

Kuroda T, Lee MM, Ragin RC, Hirobe S and Donahoe PK (1991) Müllerian inhibiting substance production and cleavage is modulated by gonadotropins and steroids Endocrinology 129 2985-2992

Lee MM, Gustafson ML, Ukiyama E, Donahoe PK, MacLaughlin DT, Wexler M and Keeping HS (1994) Developmental changes in Müllerian inhibiting substance in the Cynomolgus monkey, Macaca fascicularis. Journal of Clinical Endocrinology and Metabolism 78 615-621

Legeai L, Vigier B, Tran D, Picard JY and Josso N (1986) Monoclonal antibodies raised against bovine anti-Mülerian hormone: bovine, ovine and caprine share a set of identical epitopes Biology of Reproduction 35 1217-1225

McNatty KP, Henderson KM, Fleming JS, Clarke I], Bindon BM, Piper LR, O'Shea T, Hillard MA, Findlay IK (1990) The physiology of the Booroola ewe. In Major Genes for Reproduction in Sheep Eds JM Elsen and L. Bodin. Colloques INRA 57 105-124
McNatty KP, Smith P, Hudson NL, Heath DA, Tisdall DJ, O W-S, Braw-Tal R (1995) Development of the sheep ovary during fetal and eariy neonatal life and the effect of the fecundity gene Journal of Reproduction and Fertility Supplement 49 123-135

Monet-Kuntz C, Hochereau-de Reviers MT and Terqui M (1984) Variations in testicular androgen receptors and histology of the lamb testis from birth to puberty Journal of Reproduction and Fertility 70 203-210

Nitta H, Bunick D, Hess RA, Janulis L, Newton SC, Millette CF, Osawa Y, Shizuta Y, Toda K and Bahr JM (1993) Germ cells of the testis express P450 aromatase Endocrinology 135 1396-1401

Ortavant R (1959) Déroulement et durée du cycle spermatogenétique chez le bélier Annales de Zootechnie 8 183-244 and 271-321

Pelletier J, Garnier DH, de Reviers MM, Terqui M and Ortavant R (1982) Seasonal variation in $\mathrm{LH}$ and testosterone release in rams of two breeds Reproduction, Fertility and Development 1 299-307

Rajpert-De Meyts E and Skakkebaek NE (1996) Anti-Müllerian hormone (AMH) as a marker of altered differentiation of Sertoli cells in adult men European Testis Workshop, Geilo, Norway, April, 1996 G 13

Rey R, Lordereau-Richard I, Carel JC, Barbet P, Cate R, Roger M, Chaussain IL and Josso N (1993) Anti-Müllerian hormone and testosterone serum levels are inversely related during normal and precocious pubertal development Journal of Clinical Endocrinology and Metabolism 77 1220-1226

Rey R, al-Attar L, Louis F, Jaubert F, Barbet $\mathbf{P}$, Nihoul-Fekete C, Chaussin JL and Josso N (1996) Testicular dysgenesis does not affect expression of antiMüllerian hormone by Sertoli cells in premeiotic seminiferous tubules American Journal of Pathology 148 1689-1698

Roosen-Runge EC and Giesel LO (1950) Quantitative studies on spermatogenesis in the albino rat American Joumal of Anatomy 87 1-30

Saumande J (1981) Radioimmunoassay of estradiol-17 $\beta$ in unextracted ewe plasma Steroids 38 425-437

Seck M, Hochereau-de Reviers MT and Boomarov O (1988) Comparaisons des teneurs plasmatiques en hormone gonadotrope $\mathrm{FSH}$, durant les trois premiers mois de la vie, chez des agneaux mâles, porteurs ou non du gène 'F' de prolificité Comptes Rendus de l' Académie des Sciences, Paris (Série III) 307 433-437

Setchell BP, Locatelli A Perreau C, Pisselet C, Fontaine I, Kuntz C, Saumande J, Fontaine J and Hochereau-de Reviers MT (1991) The form and functions of the Leydig cells in hypophysectomized rams treated with pituitary extract when spermatogenesis is disrupted by heating the testes Journal of Endocrinol ogy $131 \quad 101-112$

Tran D, Meusy-Delesolle $\mathrm{N}$ and Josso $\mathrm{N}$ (1981) Waning of anti-Müllerian activity: an early sign of Sertoli cell maturation in the developing pig Biology of Reproduction $24923-931$

Tran D, Picard JY, Campargue J and Josso N (1987) Immunocytochemical detection of antiMüllerian hormone in Sertoli cells of various mammalian species including man Journal of Histochemistry and Cytochemistry 35 733-743

Vigier B, Tran D, du Mesnil du Buisson F, Heyman Y and Josso N (1983) Use of monoclonal antibody techniques to study the ontogeny of bovine anti-Müllerian hormone Journal of Reproduction and Fertility 69 207-214

Vigier B, Picard JY, Campargue J, Forrest MG, Heyman Y and Josso N (1985) Secretion of anti-Müllerian hormone by immature bovine Sertoli cells in primary culture, studied by a competition type radio-immunoassay: lack of modulation by either FSH or testosterone Molecular and Cellular Endocrinology 43 141-150

Voutilainen R and Miller WL (1987) Human Müllerian inhibitory factor messenger ribonucleic acid is hormonally regulated in the fetal testis and in granulosa cells Molecular Endocrinology $1604-608$ 